\title{
PELAKSANAAN SUPERVISI KLINIS KEPALA SEKOLAH DI SD YPPK SANTO YUSUF WAMENA KABUPATEN JAYAWIJAYA
}

\author{
Selestina Wetipo ${ }^{1)}$, Sepling Paling' ${ }^{2)}$, Leonard Sagisolo ${ }^{3)}$, Bambang Budiandoyo ${ }^{4)}$ \\ ${ }_{1,2}$ Program Studi Pendidikan Matematika Sekolah Tinggi Keguruan dan Ilmu Pendidikan Kristen Wamena, \\ Papua, Indonesia. \\ ${ }^{3,4}$ Program Studi Manajemen Pendidikan Pascasarjana Universitas Cendrawasih Papua, Indonesia. \\ email: seles2468weak@gmail.com
}

\begin{abstract}
Abstrak
Kepala sekolah mempunyai tugas melaksanakan administrasi, pengelolaan, pengembangan, pengawasan, dan pelayanan teknis untuk menunjang proses pendidikan terhadap guru. Penelitian ini dilaksanakan di SD YPPK Santo Yusuf Wamena. Tujuan penelitan adalah untuk mendeskripsikan perencanaan, pelaksanaan, tindak lanjut, dan hambatan serta dukungan. Penelitian ini menggunakan metode deskriptif dengan pendekatan analisis kualitatif. Teknik pengumpulan data menggunakan observasi, wawancara dan dokumentasi. Teknik analisis data dilakukan dengan pengumpulan data, reduksi data, dan penyajian data. Uji keabsahan data menggunakan triangulasi sumber. Kegiatan yang diamati selama proses supervisi mengenai keterampilan guru dalam pembelajaran. Hasil penelitian menunjukkan bahwa keterampilan guru dalam pembelajaran bertambah baik, terjadi peningkatan keterampilan guru, penggunaan alat peraga semakin baik, pembelajaran menjadi lebih hidup, dan hasil belajar siswa mengalami peningkatan dalam pencapaian KKM dibandingkan sebelum diadakan supervisi. Hal-hal yang mendukung dan menghambat pelaksanaan supervisi klinis adalah: faktor pendukung; Guru menjadi termotivasi untuk meningkatkan mutu saat kegiatan belajar mengajar berlangsung dan siswa menjadi lebih aktif dan berinteraksi ketika pembelajaran berlangsung. Faktor penghambat; pelaksanaan supervisi terkadang berbenturan dengan kegiatan yang lain. Tindak lanjut dari hasil supervisi klinis yaitu Kepala Sekolah selalu berupaya membimbing guru, melakukan pembinaan kepada guru untuk meningkatkan hasil belajar siswa. Kepala Sekolah juga memberikan pelatihan yang dilaksanakan sesuai dengan jadwal kegiatan sekolah.
\end{abstract}

Kata kunci: Supervisi Klinis, Kepala Sekolah, SD YPPK St. Yusuf, Wamena, Jayawijaya

\begin{abstract}
The principal has the task of carrying out administration, management, development, supervision, and technical services to support the education process for the teacher. This research was conducted at SD YPPK Santo Yusuf Wamena. The purpose of research is to describe planning, implementation, follow-up, and obstacles and support. This study uses a descriptive method with a qualitative analysis approach. The technique of data collecting uses observation, interviews and documentation. Data analysis techniques are done by data collecting, data reducing, and data presenting. The validity test of the data uses source triangulation. The observation during the supervision process regarded the teachers skills in learning. The results showed that the teachers's skills in learning improved, such as; there was an increase in teacher skills, the use of teaching aids was getting better, learning became more interactive, and students learning outcomes
\end{abstract}


improved in KKM achievement compared to before supervision. Things that support and obstruct the implementation of clinical supervision are: supporting factors; teachers become motivated to improve quality when teaching and learning activities and students become more active and interact when learning activities. Obstruct factor; the implementation of supervision sometimes collides with other activities. Follow-up from the results of clinical supervision, namely the Principal always tries to guide the teachers, to provide guidance to the teachers to improve students learning outcomes. The Principal also provides training carried out according to the school activity schedule.

Keywords: Clinical Supervision, Principal, SD YPPK St. Yusuf, Wamena, Jayawijaya

\section{PENDAHULUAN}

Tujuan pengajaran sebagaimana tujuan sekolah, pada umumnya dapat berupa tuntutan, untuk mewujudkan kemampuan akademis, ketrampilan, sikap, dan mental serta kepribadian yang harus dimiliki peserta didik sebagai output dari proses pembelajaran. Menurut Undang-Undang Nomor 20 tahun 2003 mengatakan bahwa tujuan pendidikan nasional adalah untuk mengembangkan potensi peserta didik agar menjadi manusia yang beriman, berakhlak mulia, sehat, berilmu, cakap, kreatif, mandiri dan menjadi warga Negara yang demokratis serta bertanggung jawab.

Guru merupakan komponen sumber daya manusia yang harus dibina dan dikembangkan terus-menerus juga, merupakan penentu keberhasilan peningkatan kualitas pendidikan di sekolah yang diberi tanggung jawab untuk mengelola, mewujudkan visi misi, dan tujuan sekolah.

Menurut Undang-Undang No. 14 Tahun 2005 pasal 1 ayat (1) menyatakan bahwa guru adalah pendidik professional dengan tugas utama mendidik, mengajar, membimbing, mengarahkan, melatih, menilai, dan mengevaluasi peserta didik pada pendidikan formal, pendidikan dasar, dan pendidikan menengah.

Sebagai pengajar, guru harus terampil menyusun program mengajar untuk kurun waktu tertentu, membuat persiapan dalam proses pembelajaran, menyiapkan alat peraga atau media pembelajaran, pelaksanaan pembelajaran, pelaksanaan evaluasi hasil pembelajaran. Untuk menjamin agar guru melaksanakan tugasnya secara professional, maka diperlukan tindakan supervisi klinis. Supervisi klinis merupakan suatu bentuk bantuan profesional yang diberikan secara sistematik kepada guru/calon guru berdasarkan kebutuhan dalam hal ini kegiatan proses bejalar mengajar dengan tujuan membina ketrampilan mengajar mereka. Supervisor sebagai pengawas pendidikan bertindak sebagai stimulator, pembimbing dan konsultan bagi guru-guru dalam perbaikan pengajaran dan menciptakan situasi belajar mengajar yang baik. Selain itu, supervisi diharapkan mampu membawa dampak perkembangan yang baik bagi kemajuan proses pengajaran melalui peningkatan kurikulum yang ada di sekolah sebagai salah satu sarana dalam meningkatkan mutu pendidikan.

Sudarwan, dan Khairil manyatakan bahwa supervisi klinis merupakan suatu bentuk bimbingan profesional yang diberikan pada guru berdasarkan kebutuhannya, melalui siklus yang sistematik, diawali dengan pertemuan perencanaan, observasi yang cermat, dan kajian balikan segera dan seobjektif mungkin tentang penampilan mengajarnya yang nyata, 
untuk meningkatkan keterampilan mengajar dan sikap professional guru itu.

Pelaksanaan bimbingan pun dilakukan secara professional. Bimbingan ini dilakukan dengan berdasarkan pada kebutuhan dan kesulitan yang dialami oleh guru, dalam melakukan kegiatan pembelajaran yang mereka lakukan. Dengan supervisi klinis akan membantu memodifikasi pola-pola Pembelajaran yang tidak atau kurang efektif.

\section{KAJIAN LITERATUR}

Supervisi pendidikan di sekolah, merupakan bimbingan, pelayanan dan bantuan dari supervisor kepada yang disupervisi (pada umumnya guru), supaya para guru dapat meningkat keahlian profesionalnya, dapat menjadi guru yang lebih baik dan menghasilkan murid yang lebih baik pula (Rifai, 2001).

Sudarwan, dan Khairil (2012) mendiskripsikan bahwa supervisi klinis sebagai bantuan profesional yang diberikan kepada guru yang mengalami masalah dalam melaksanakan pembelajaran agar guru tersebut dapat mengatasi masalah yang dialaminya berkaitan dengan proses pembelajaran. Muslim (2009) kegiatan pembinaan performansi guru dalam mengelola proses belajar mengajar dan supervisi klinis termasuk aktivitas-aktivitas yang terjadi di dalam kelas. Ia berkenaan dengan perbaikan mengajar dan belajar melalui observasi langsung terhadap tindakan guru dan siswa dalam lingkungan belajar. Dengan demikian penulis dapat menyimpulkan, bahwa makna supervisi klinis adalah bantuan profesional yang diberikan oleh kepala sekolah kepada guru yang mengalami masalah dalam pembelajaran agar guru yang bersangkutan dapat mengatasi masalahnya, dengan menempuh langkah yang sistematis.

\section{Prinsip-Prinsip Supervisi Klinis}

Sudarwan, dan Khairil mengemukakan bahwa prinsip-prinsip dalam supervisi klinis sebagai berikut:

a. Supervisi klinis yang dilaksanakan harus berdasarkan inisiatif dari para guru lebih dahulu. Perilaku supervisor harus sedemikian tektis sehingga guru-guru terdorong untuk berusaha meminta bantuan dari supervisor;

b. Terwujudnya hubungan manusiawi yang bersifat interaktif dan rasa kesejawatan;

c. Terciptanya suasana bebas, dimana setiap orang, dalam hal ini guru, bebas mengemukakan apa yang dialaminya. Supervisor berusaha untuk mengetahui dan memahami apa yang diharapkan guru;

d. Objek kajian adalah kebutuhan profesional guru yang riil dan yang mereka alami;

e. Perhatian dipusatkan pada unsur-unsur yang spesifik yang harus diangkat untuk diperbaiki.

Makawimbang (2013) juga berpendapat bahwa terdapat beberapa prinsip umum yang menjadi dasar dalam pelaksanaan supervisi klinis, sebagai berikut:

a. Terpusat pada guru/calon guru ketimbang supervisor, prinsip ini menekankan prakarsa dan tanggung jawab dalam meningkatkan/mengembangkan

keterampilan mengajar dan menganalisis serta mencari cara-cara meningkatkan keterampilan mengajar itu lebih baik.

b. Hubungan guru/calon guru dengan supervisor lebih interaktif ketimbang direktif. Prinsip ini menekankan bahwa antara supervisor dan guru/calon guru pada hakikatnya sederajat dan saling membantu dalam meningkatkan kemampuan dan sikap profesionalnya.

c. Demokraktik ketimbang otoritatif. Prinsip ini menekankan kedua belah pihak harus bersifat terbuka, artinya masing-masing 
pihak supervisor dan guru/calon guru berhak mengemukakan pendapat secara bebas, namun kedua pihak berkewajiban mengkaji dan mempertimbangkan pendapat pihak lain untuk mencapai kesepakatan.

d. Sasaran supervisi terpusat pada kebutuhan dan aspirasi guru/calon guru. Prinsip ini mengemukakan bahwa kebutuhan mendapatkan pelayanan supervise itu bersumber dan dirasakan manfaatnya oleh guru/calon guru.

e. Umpan balik dari proses belajar mengajar guru/calon guru diberikan dengan segera dan hasil peninjauan/penilaianya harus sesuai dengan kotrak yang telah disetujui bersama.

f. Supervisi yang diberikan bersifat bantuan dengan tujuan untuk meningkatkan kemampuan mengajar dan sikap professional. Prinsip ini menekankan bahwa bila guru/calon guru sudah matang dan memiliki sikap professional yang tinggi, maka tugas supervisor sudah beres, dengan kata lain supervisor sudah boleh membiarkan/melepaskan guru/calon guru tersebut secara mandiri.

g. Pusat perhatian pada waktu berlangsung supervise dalam kegiatan belajar mengajar tertentu hanya pada beberapa keterampilan mengajar saja. Prinsip ini menekankan bahwa meskipun keterampilan mengajar itu dapat digunakan secara interaktif, tetapi untuk meningkatkan keterampilan tertentu dapat dilakukan secara terisolasi agar mudah dikontrol dan di amati.

Berdasarkan beberapa pendapat di atas, maka dapat dikatakan bahwa, prinsip-prinsip ini hanya berfokus pada kepercayaan penampilan mengajar kepada guru/calon guru untuk lebih ke perbaikan proses pengajaran agar pengajarannya lebih professional bagi guru/calon guru.

\section{Tahapan Supervisi Klinis}

Mosher dan Purpel (dalam Wahyudi, 2009) membagi tahapan supervisi klinis menjadi tiga tahapan yaitu, planning, observation, and evaluation or analysis. Pidarta (1992) mengatakan bahwa pelaksanaan supervisi klinis tidak terlepas dari tahapan-tahapan yang sistematis. Sebagaimana langkah-langkah supervisi klinis yang ditempuh oleh Neagley adalah sebagai berikut:

a. Menciptakan hubungan baik antara supervisor dengan guru bersangkutan, agar makna supervisi menjadi jelas bagi guru sehingga kerjasama dan partisipasinya meningkat.

b. Merencanakan aspek perilaku yang akan diperbaiki serta pada sub pokok bahasan.

c. Merencanakan strategi observasi.

d. Mengobservasi guru mengajar, boleh menggunakan alat bantu.

e. Menganalisis proses belajar mengajar oleh supervisor dan guru secara terpisah.

f. Merencanakan pertemuan, boleh juga dengan pihak ketiga yang ingin mengetahui.

g. Melaksanakan pertemuan, guru diberi kesempatan menanggapi cara mengajar sebelum dibahas Bersama.

h. Membuat rencana baru bila aspek perilaku belum dapat diperbaiki dan mengulangi dari langkah awal sampai akhir.

Merujuk pada pendapat di atas, maka dapat dirumuskan tahapan-tahapan pelaksanaan supervisi klinis adalah melakukan perencanaan secara mendetail, melaksanakan pengamatan secara cermat, dan menganalisis hasil pengamatan serta memberikan umpan balik kepada guru yang bersangkutan. Ketiga tahapan tersebut jika dilaksanakan dengan benar maka tujuan supervisi akan tercapai. 


\section{METODE PENELITIAN}

Jenis penelitian ini merupakan penelitian deskriptif kualitatif yang dilakukan di SD YPPK Santo Yusuf Wamena pada semester genap tahun pelajaran 2015/2016. Penelitian ini menggunakan metode deskriptif dengan pendekatan analisis kualitatif. Teknik pengumpulan data menggunakan observasi, wawancara mendalam dan dokumentasi. Data yang telah diperoleh selanjutnya dianalisis dengan cara reduksi data, penyajian data, dan penarikan kesimpulan/verifikasi. Pengujian Kredibilitas Data Perpanjangan pengamatan, meningkatkan ketekunan, pemeriksaan teman sejawat, member Chek (Pengecekan anggota). Teknik supervisi yang digunakan adalah kunjungan kelas. Kegiatan yang diamati selama proses supervisi mengenai keterampilan guru dalam pembelajaran.

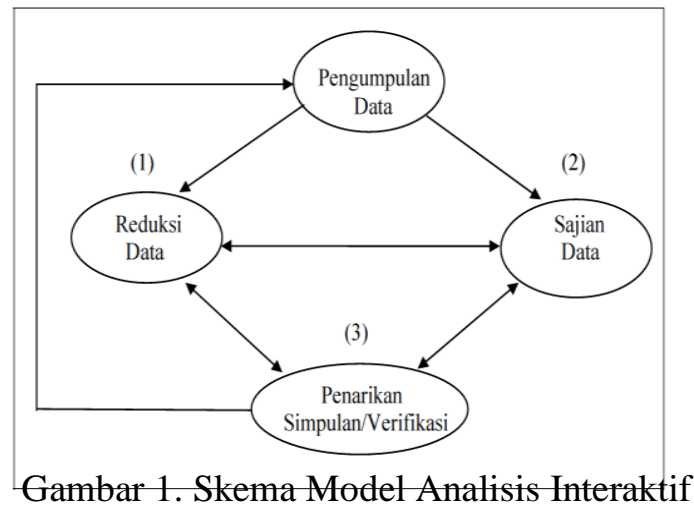

\section{HASIL DAN PEMBAHASAN}

Di dalam penelitian ini, penulis menyajikan beberapa komponen utama sesuai dengan hasil penelitian. Berkaitan dengan pernyataan teori tersebut.

\section{Perencanaan Supervisi Klinis}

Kepala sekolah sebagai supervisor, mengatakan di forum rapat bahwa menjalin hubungan dengan baik bersama guru-guru, sebelum melakukan supervisi klinis dan merencanakan dalam hal ini, menjadwalkan untuk melakukan supervisi 1 Tahun dua kali dalam bulan Maret dan September. Kepala sekolah sebagai supervisor dan juga dapat menentukan fokus observasi, alat bantu (instrument) observasi, dan menentukan teknik pelaksanaan observasi. Hal-hal di atas menunjukan bahwa kepala sekolah sebagai supervisor yang berhasil dalam perencanaan pelaksanaan supervise klinis

Sesuai dengan hasil penelitian di atas, menurut Sahartian (2008), dalam ruang lingkup perencanaan supervisi meliputi: (a) Persiapan pelaksanaan Kurikulum Tingkat Satuan Pendidikan; (b) Persiapan pelaksanaan dan penilaian pembelajaran oleh kepala sekolah; (c) Pencapaian standar kompetensi lulusan, standar proses, standar isi, dan peraturan pelaksanaannya; dan; (d) Peningkatan mutu pembelajaran melalui:

a. Model kegiatan pembelajaran yang mengacu pada Standar Proses.

b. Proses pembelajaran untuk meningkatkan kemampuan peserta didik menjadi yang kreatif, inovatif, mampu memecahkan masalah, berpikir kritis.

Hasil penelitian menunjukkan bahwa sesuai pendapat Sahartian di atas ternyata program pembinaan kemampuan mengajar guru yang merencanakan oleh kepala sekolah sesuai dasar fase-fase yang diharapkan. Selain itu juga di dalam program sudah tercamtumkan sasaran dan jadwal mengenai pelaksanaan supervisi tersebut secara terperinci, maka peneliti dapat sampaikan bahwa pelaksnaan supervisi di SD YPPK Sannto Yusuf Wamena menyusun perencanaan sesuai dengan standar proses.

Kepala sekolah sebagai supervisor, perencanaan harus dirumuskan secara jelas dan dikerjakan secara profesional terhadap tugas-tugas guru. Hal ini dapat terjadi karena kepala sekolah SD YPPK Santo Yusuf mempunyai pengalaman yang cukup baik. Maka kepala sekolah dapat penyusunan program pengajaran, penyiapan perangkat 
pembelajaran (Satuan acuan pelajaran, rencana pembelajaran, alat evaluasi, penyiapan media pembelajaran dan lain-lain). Sehingga peneliti dapat sampaikan bahwa perencanaan kepala sekolah secara baik, untuk mencapai tujuan yang efisien dan efektif.

\section{Pelaksanaan Supervisi Klinis}

Dengan demikian supervisi klinis yang dilakukan oleh kepala sekolah sangat fleksibel memberikan peluang dan kesempatan kepada guru-guru untuk mengembangkan kemampuan professional mereka sendiri, dalam arti tidak harus selalu berharap dan menunggu supervisi dari kepala sekolah. Hal tersebut sesuai hakekat guru, sebab mereka bertanggung jawab secara professional untuk terus menerus meningkatkan kemampuanya.

Dalam pelaksanaanya pembinaan professional tersebut, dilakukan melalui suatu jaringan dan system pembinaan kreatif dengan melibatkan secara aktif seluruh unsur pembina guru dalam perbaikan pengajaran, karena kepala sekolah tidak pernah campur aduk dengan tugas guru-guru dalam hal pengajaran di dalam kelas. Guru-guru tidak merasa terganggu karena guru-guru merasa kepala sekolah berada dalam ruang kelas saat proses pembelajaran berlangsung sangat penting untuk memperbaiki pengajaran kedepan, demikian pula kepala sekolah sampaikan saat rapat bahwa saya akan masuk supervisi, maka untuk observasi tidak bersifat menilai namun propesionalismenya, kepala sekolah juga observasi untuk memperbaiki pengajaran kedepan dan untuk tindak lanjut. Kepala sekolah saat observasi mencatat itu, tidak hanya merekam hal-hal yang guru-guru dalam hal proses pembelajaran berlangsung yang perlu diperbaiki sebagai tindak lanjut.

Menurut Pidarta, (1992) secara garis besar cara atau teknik pelaksanaan supervisi dapat digolongkan menjadi dua, yaitu teknik perseorangan dan teknik kelompok.

1. Teknik perseorangan

Teknik perseorangan ialah supervisi yang dilakukan secara perseorangan. Beberapa kegiatan yang dapat dilakukan antara lain:

a. Mengadakan kunjungan kelas (classroom visition).

b. Mengadakan kunjungan observasi (obsertvation visits)

c. Membimbing guru-guru tentang cara-cara mempelajari pribadi siswa dan atau mengatasi problema yang dialami siswa

d. Membimbing guru-guru dalam hal-hal yang berhubungan dengan pelaksanaan.

2. Teknik kelompok

Supervisi yang dilakukan secara kelompok. Beberapa kegiatan yang dapat dilakukan antara lain:

a. Mengadakan pertemuan atau rapat (meeting)

Seorang kepala sekolah yang baik umumnya menjalankan tugasnya, berdasarkan rencana yang telah disusunnya.

b. Mengadakan diskusi kelompok (group discussions)

Diskusi kelompok dapat diadakan dengan membentuk kelompok-kelompok guru bidang study sejenis.

Mengadakan penataran-penataran (inservice-traning)

c. Teknik supervisi kelompok yang dilakukan melalui penataran-penataran sudah banyak dilakukan.

Sedangkan Menurut Gwyn dalam Bafadal (2004), teknik supervisi digolongkan menjadi dua kelompok, yaitu teknik perorangan dan teknik kelompok. Teknik supervisi individual meliputi: 1) kunjungan kelas, 2) percakapan pribadi, 3) kunjungan antar kelas, 4) penilaian sendiri. Sedang teknik supervisi kelompok meliputi: 1) 
kepanitiaan, 2) kursus, 3) laboratorium kelompok, 4) bacaan terpimpin, 5) demonstrasi pembelajaran, 6) perjalanan staff, 7) diskusi panel, 8) perpustakaan profesional, 9) organisasi professional, 10) bulletin supervisi, 11) sertifikasi guru, 12) tugas akhir, 13) pertemuan guru.

Hasil penelitian pelaksanaan menunjukkan bahwa, ternyata program pembinaan kemampuan mengajar guru yang disusun oleh kepala sekolah sudah sesuai dengan dasar fase-fase yang diharapkan. Selain itu juga di dalam program sudah tercamtumkan sasaran dan jadwal mengenai pelaksanaan pembinaan tersebut secara terperinci. Ada beberapa teknik yang biasa digunakan kepala sekolah dalam mensupervisi gurunya, namun dalam penelitian ini hanya indicator, kunjungan kelas, semangat kerja guru, pengembangan metode dan evaluasi, dan rapat-rapat pembinaan, yang kami teliti.

Supervisi pengajaran dapat dilakukan dengan sistematis melalui tahapan-tahapan sehingga perbaikan yang dilakukan terhadap proses pembelajaran dapat fokus dan rasional. Selain supervisi perorangan maupun kelompok, penilaian Kinerja Guru (PKG) adalah penilaian dari tiap butir kegiatan tugas utama guru dalam rangka pembinaan karir, kepangkatan, dan jabatannya.

\section{Tindak Lanjut Pelaksanaan Supervisi Klinis}

Berdasarkan uraian di atas, peneliti dapat simpulkan bahwa kepala sekolah menyimpulkan kembali dengan kesepakatankesepakatan bersama guru untuk memperbaiki pengajaran sebagai tindak lanjut, sedangkan kepala sekolah/supervisor sebagai atasan mengkaji data dari hasil pengamatan mulai dari kelas satu sampai dengan kelas enam, kepala sekolah tidak hanya observasi di kelas satu A, B dan C namun, kepala sekolah juga sebagai supervisor di sekolah, observasi di setiap kelas yang ada, kepala sekolah menyimpulkan hasil observasi sebagai tindak lanjut dari semua yang kepala sekolah mengadakan supervisi klinis untuk memperbaiki pengajaran kedepan.

Hasil supervisi perlu ditindak lanjuti agar memberikan dampak yang nyata bagi peningkatkan profesionalisme guru. Dampak nyata ini diharapkan dapat dirasakan masyarakat maupun stakeholders. Tindak lanjut tersebut berupa: penguatan dan penghargaan diberikan kepada guru yang telah memenuhi standar, teguran yang bersifat mendidik diberikan kepada guru yang belum memenuhi standar dan guru diberi kesempatan untuk mengikuti pelatihan/penataran lebih lanjut. Tindak lanjut dari hasil analisis merupakan pemanfaatan hasil supervisi. Dalam materi pelatihan tentang tindak lanjut hasil supervisi akan dibahas mengenai pembinaan dan pemantapan instrumen.

Berdasarkan hasil penelitian peneliti ditemukan di internet di atas, bahwa kepala sekolah juga melakukan evaluasi pembinaan sesuai berdasarkan catatan-catatan pada format kunjungan kelas kepada guru untuk setiap proses pembelajaran sebagai tindak lanjut, sebagai bahan analisis dan masukan dalam membuat program pembinaan guru tindak lanjut pada semester berikutnya.

Konsep tindak lanjut hasil supervisi akademik terhadap guru, perlu sampaikan secara umum lagi dan tujuan pembelajaran dibicarakan secara umum, dalam rapat dewan guru, agar memperbaiki pengajaran dengan secara individual yang efektif dan efisien untuk perkembangan keterampilan mengajar guru atau meningkatkan profesionalisme guru, setidaknya dapat mengurangi kendalakendala yang muncul. 


\section{Hambatan Dan Dukungan Pelaksanaan Supervisi Klinis}

Berdasarkan hasil wawancara, maka peneliti dapat simpulkan bahwa kepala sekolah sebagai supervisor, sebelum melakukan diskusi balikan, ada memberi penguatan, (motivasi), memberi dukungan, tidak bersifat menyalakan guru-guru, namun kepala sekolah lebih ke masukan untuk memperbaiki pengajaran kedepan lebih baik lagi, yaitu proses pengajaran.

Kepala sekolah sebagai supervisor menghindari saran-saran secara langsung dari guru-guru, tidak sebar luaskan hasil pengamatan kepada guru-guru lain, agar tidak terjadi hambatan, namun kepala sekolah kasih tahu kepada guru yang bersangkutan. Sehingga di SD YPPK Santo Yusuf Wamena tidak mengalami hambatan secara umum namun selama ini yang ada lebih ke perorangan saja, maka proses pembelajaran selama ini berjalan baik dan selalu memberi dukungan kepada guru.

Menurut, Purwanto (2004), banyak faktor yang mempengaruhi kinerja seseorang, baik yang berasal dari dalam diri maupun yang berasal dari luar, menyatakan ada 2 (dua) macam faktor yang dapat mempengaruhi kinerja seseoarng yaitu:

\section{Faktor Individual}

Yaitu faktor- faktor yang meliputi sikap, sifat-sifat kepribadian, sifat fisik, keinginan atau motivasinya, umur, jenis kelamin, pendidikan, pengalaman kerja, latar belakang budaya dan variabelvariabel personal lainnya.

\section{Faktor Situasional}

Faktor sosial dan organisasi, meliputi: kebijaksanaan organisasi, jenis latihan dan pengawasan, system upah dan lingkungan sosial.

1. Faktor fisik dan pekerjaan, meliputi: metode kerja, desain dan kondisi alat-alat kerja, penataan ruang kerja dan lingkungan kerja (seperti penyinaran, kebisingn dan fentilasi)

Berdasarkan hasil penelitian yang diperoleh menyatakan bahwa sebagian kompetensi supervisor masih lemah seperti yang mengemukakan oleh Purwanto di atas, maka yang menjadi faktor utama atau hambatan yaitu faktor individual dan faktor situasional. Hal inilah yang menjadi salah satu faktor hambatan dalam pelaksanaan supervisi pengajaran supervisor seharusnya menganalisis kondisi setiap guru yang akan disupervisi secara mendalam, bukan saja dari penampilan luar, melainkan juga mencoba membuka isi hatinya, suasana hati, dan kata hatinya untuk mendapatkan pengetahuan yang dalam tentang guru itu.

Hal demikian dapat terjadi karena kepala sekolah sebagai supervisor, tidak melihat dari isi hatinya seseorang dan bisa di katakan motivasi kurang dari guru itu sendiri, maka kepala sekolah merasakan bahwa hal ini sala satu hambatan yang terjadi. Namun hal ini tidak semua guru yang buat tapi hanya satu atau dua guru yang buat dan selain dari itu ada yang mendengarkan apa yang kepala sekolah sampaikan, maka guru-guru juga memberi dukungan yang baik pula kepada kepala sekolah sebagai supervisor di SD YPPK Santo Yusuf Wamena.

Adapun pengaruh dari supervisi pendidikan oleh Kepala Sekolah sebagai supervisor akan membawah dampak dalam pengaplikasian guru mengajar yaitu tujuan pembelajaran, metode mengajar dan penggunaan alat peraga, untuk melihat hal ini kepala sekolah masuk observasi pada waktu guru-guru mengajar, ternyata ada perubahanperubahan yang terjadi dari tindak lanjut sehingga dari perubahan itu membawah dampak yang positif ke siswa sebagai penerima informasi. Kepala sekolah sebagai supervisor sangat senang ketika melihat dampak dari supervisi klinis. 


\section{Manfaat Supervisi Klinis}

Berdasarkan hasil wawancara di atas peneliti dapat simpulkan bahwa, adapun pengaruh dari supervisi pendidikan oleh Kepala Sekolah sebagai supervisor ada manfaat dalam pengaplikasian guru mengajar yaitu tujuan pembelajaran, metode mengajar dan penggunaan alat peraga, untuk melihat hal ini kepala sekolah masuk observasi pada waktu guru-guru mengajar, ternyata ada perubahan-perubahan yang terjadi dari tindak lanjut sehingga dari perubahan itu mendapatkan manfaat yang positif ke siswa dan guru sebagai penerima informasi. Guru dapat meningkatkan metode mengajar yang lebih propesional. Siswa dapat meningkatkan prestasi belajar. kepala sekolah sebagai supervisor sangat bangga ketika melihat hasil dari supervisi klinis.

Menurut Mulyasa (2002) segala usaha pejabat sekolah dalam memimpin guru-guru dan tenaga kependidikan lainya akan membawah dampak yang baik untuk memperbaiki pengajaran termasuk menstimulasi, menyeleksi pertumbuhan dan perkembangan jabatan guru-guru, menyeleksi dan merevisi tujuan-tujuan pendidikan, bahan pengajaran dan metode-metode mengajar serta evaluasi pengajaran.

Berdasarkan hasil penelitian yg dikaitkan teori mulyasa di atas, peneliti dapat sampaikan bahwa dampak pelaksnaan supervisi di SD YPPK Sannto Yusuf Wamena bersifat umum yaitu memperbaiki pengajaran dan metode mengajar, sehingga kepala sekolah sebagai pemimpin merasa senang dan guru-guru pun demikian karena adanya dampak dari supervisi yang positif.

Hal demikian dapat terjadi karena kepala sekolah sebagai supervisor, membangun hubungan dan mis komunikasi secara efektif, pada guru dan membina guruguru dalam rangka memperbaiki pengajaran, mambawah dampak yang positif dalam hal ini tujuan pembelajaranmetode mengajar dan perbaikan pengajaran atau peningkatan kemampuan, kemudian di transfer kedalam perilaku mengajar sehingga tercipta situasi belajar mengajar yang lebih baik, yang akhirnya juga meningkatkan pertumbuhan peserta didik.

\section{KESIMPULAN DAN SARAN}

Hasil penelitian menunjukkan bahwa sesuai program pembinaan kemampuan mengajar guru yang merencanakan oleh kepala sekolah sesuai dasar fase-fase yang diharapkan. Selain itu juga di dalam program sudah tercantum sasaran dan jadwal mengenai pelaksanaan supervisi secara terperinci, maka peneliti dapat sampaikan bahwa pelaksanaan supervisi di SD YPPK Santo Yusuf Wamena menyusun perencanaan sesuai dengan standar proses.

Hasil penelitian menunjukkan bahwa keterampilan guru dalam pembelajaran bertambah baik, terjadi peningkatan keterampilan guru, penggunaan alat peraga semakin baik, pembelajaran menjadi lebih hidup, dan hasil belajar siswa mengalami peningkatan dalam pencapaian KKM dibandingkan sebelum diadakan supervisi. Hal-hal yang mendukung dan menghambat pelaksanaan supervisi klinis adalah: faktor pendukung; Guru menjadi termotivasi untuk meningkatkan mutu saat kegiatan belajar mengajar berlangsung dan siswa menjadi lebih aktif dan berinteraksi ketika pembelajaran berlangsung. Faktor penghambat; pelaksanaan supervisi terkadang berbenturan dengan kegiatan yang lain. Tindak lanjut dari hasil supervisi klinis yaitu Kepala Sekolah selalu berupaya membimbing guru, melakukan pembinaan kepada guru untuk meningkatkan hasil belajar siswa. Kepala Sekolah juga memberikan pelatihan yang dilaksanakan sesuai dengan jadwal kegiatan sekolah. 
Berdasarkan hasil penelitian, diharapkan kepada kepala sekolah SD YPPK Santo Yusuf dan lainya agar dapat memperbaiki dan meningkatkan keterampilan guru dalam proses belajar mengajar. Disarankan juga kepada guru-guru SD YPPK Santo Yusuf Wamena untuk terus memberi kepercayaan kepada, kepala sekolaah agar dapat meningkatkan keterampilan guru dalam proses belajar mengajar. Untuk peneliti berikutnya disarankan untuk menggunakan teknik pengumpulan data lebih beragam lagi, agar hasil yang didapatkan lebih optimal.

\section{REFERENSI}

Bafadal. 2004. Manajemen Perlengkapan Sekolah. Jakarta: PT. Bumi Aksara.

Makawimbang, J.H. 2013. Supervisi Klinis Teori dan Pengukurannya. Bandung: Alfabeta.

Mulyasa. E. 2002. Manajemen Berbasis Sekolah. Bandung PT. Remaja Rosdakaryc, Moedjiarto.

Muslim, B. Sri. 2009. Supervise Pendidikan Meningkatkan Kualitas

Profesionalisme Guru. Alfabeta.
Purwanto, Ngalim. 2004. Administrasi dan supervisi pendidikan. Bandung: Remaja Rosdakarya OffesetBandung.

Pidarta, Made. 1992. Pemikiran Tentang Supervisi Pendidikan. Jakarta: PT. Bumi Aksara.

Rifai, Moh. 2001. Teknologi Pengajaran. Bandung : Sinar Baru Algesindo.

Sahertian, Piet A. 2008. Konsep Dasar dan Teknik Supervisi Pendidikan (Dalam Rangka Pengembangan Sumber Daya Manusia). Jakarta: Rineka Cipta.

Sudarwan, D. dan Khairil. 2012. Profesi Kependidikan. Bandung: Alfabeta.

Undang-Undang Nomor 20 Tahun 2003 tentang Sistem Pendidikan Nasional.

Undang-Undang No. 14 Tahun 2005 Tentang Guru dan Dosen.

Wahyudi. 2009. Kepemimpinan Kepala Sekolah Dalam Organisasi Pembelajaran. Bandung: Alfabeta. 